\title{
Minimization of phosphorus in the fermentation media of Escherichia coli producing a model recombinant protein
}

\author{
M. K. Witt • T. F. O'Dwyer • G. Walsh
}

Received: 20 November 2012/Revised: 25 February 2014/Accepted: 28 April 2014/Published online: 20 May 2014

(C) Islamic Azad University (IAU) 2014

\begin{abstract}
In the biotechnology sector, a main processing goal is the production of high cell (and hence product) yields. Therefore, little consideration is traditionally given to the potential environmental impacts of excess culture media ingredients. This study investigated the scope for reducing the quantities of phosphorus $(\mathrm{P})$ present in both a complex terrific broth (TB) and semi-defined minimal media 9/yeast extract (M9/YE) fermentation media used to culture a model Escherichia coli strain engineered to produce a recombinant $\beta$-galactosidase. Reductions of up to $70 \%$ did not adversely affect biomass yields attained; however, further $\mathrm{P}$ minimization leads to a drop in dry cell weight obtained, particularly in the case of semi-defined media. $\mathrm{P}$ concentration in TB media had little effect upon total recombinant protein expression levels achieved. In the case of M9/YE media, reductions $>70 \% \mathrm{P}$ negatively affected product expression levels. Protein functionality, assessed by $k_{\mathrm{m}}$ and $V_{\max }$, was not influenced by the type of media nor the $\mathrm{P}$ concentration present. Overall, the results indicate that $\mathrm{P}$ can be reduced by a minimum of $70 \%$ without adversely affecting the biomass yield, the recombinant protein yield or functionality. Such reductions should lead to significant $\mathrm{P}$ savings in the large-scale manufacturing of proteins produced by genetic engineering in E. coli.
\end{abstract}

Keywords Phosphorus - Eutrophication - Waste minimization · Biopharmaceutical

M. K. Witt ( $₫)$ · T. F. O'Dwyer · G. Walsh

Department of Chemical and Environmental Sciences and

Materials and Surface Science Institute, University of Limerick,

Limerick, Ireland

e-mail: madlen.witt@ul.ie

\section{Introduction}

Microbial fermentation, employed to produce various biomolecules of industrial or medical use, remains a core activity within the global biotechnology industry (Demain and Vaishnav 2009). Among the most prominent examples of such activity is the production of protein therapeutics (biopharmaceuticals) in Escherichia coli via genetic engineering. Examples of such recombinant proteins include insulin, antibody fragments and various cytokines such as interferons and colony-stimulating factors. Some industrial enzymes (e.g., amidases, mammalian chymosin, lipases, proteases) as well as proteins used for research purposes (e.g., restriction endonucleases, DNA and RNA polymerases, ligase) also are produced by recombinant means in E. coli (Choi et al. 2006; Eiteman and Altman 2006). Such manufacturing activity initially involves growth of the producer cell by fermentation (upstream processing), followed by product recovery and often further purification (downstream processing) (Behme 2009). Spent fermentation media invariably represent the major waste stream produced by such manufacturing practices.

Design of fermentation culture media composition has traditionally focused upon maximizing product yield. Media ingredients are relatively inexpensive and are often added in excess. Potential environmental consequences of unutilized media ingredients were generally given little consideration during process development (Cliffe et al. 2010). Of particular environmental concern is the phosphorus (P) content of such waste media which, if not properly treated, can lead to eutrophication in water bodies, thereby leading to significantly reduced water quality (Khan and Ansari 2005).

A preliminary study has indicated that the phosphorous content of selected media used to produce a niche product 
(plasmid DNA) could be reduced without affecting product yield (Cliffe et al. 2010). The current study investigates the potential for $\mathrm{P}$ minimization in the context of what may quantitatively be the most widespread global application of modern microbial biotechnology, the production of recombinant proteins in engineered $E$. coli. Results obtained in the context of plasmid-based synthesis may not automatically correlate to protein synthesis. Moreover, protein production raises several additional issues not pertinent to plasmid production, which necessitate additional investigation in terms of how/if such issues are affected by phosphorous minimization. These include the fact that proteins display an intrinsic functional activity and that recombinant proteins produced in E. coli generally accumulate as a mixture of biologically active, soluble form and biologically inactive, insoluble form (inclusion bodies). Finally, this study also incorporates investigation of $\mathrm{P}$ minimization using a more chemically defined [minimal media 9 (M9) based] fermentation media, in line with recent regulatory and manufacturing trends within the biopharmaceutical sector. The research described in the paper was carried out in laboratories in the University of Limerick, Limerick, Ireland, in 2010-2011.

\section{Materials and methods}

Materials and microbial strains

Commercial $\beta$-galactosidase (G8511), EZBlue (G1041) as well as all other chemicals employed were purchased from Sigma-Aldrich, Dublin, Ireland, unless otherwise stated. E. coli strain W3110 was purchased from DSMZ (Braunschweig, Germany). E. coli MC1061 and the pProEx-HTb plasmid (available from Invitrogen, Carlsbad, USA) were present in the laboratory collection of Professor Gary Walsh.

\section{Production of model strain}

Genomic DNA from E. coli W3110 was prepared using the Qiagen DNeasy Blood and Tissue kit. This template DNA was employed to amplify the lac Z gene via PCR using ExTaq (Takara Bio Inc., Shiga, Japan) polymerase. The primers were designed to include restriction enzyme recognition sites for BamH1 (forward primer) and Hind III (reverse primer). The amplified gene was restricted and inserted into the restricted plasmid pProEx-HTb via T4 ligase. Ligated plasmids were transformed into the propagation strain $E$. coli $\mathrm{DH} 5 \alpha$ using the $\mathrm{CaCl}_{2}$ method (Sambrook and Russell 2001). Resulting strains were tested for presence of insert and the nucleotide sequence of the lac Z gene. A suitable clone was selected, and the plasmid
DNA was purified and transformed into the expression strain E. coli MC1061. Optimization of recombinant protein expression was carried out to achieve maximum soluble recombinant protein concentration (Sambrook and Russell 2001).

Cell growth, recovery and lysis

The model recombinant strain was initially grown in Luria-Bertani broth (LB) for $15 \mathrm{~h}$ at $37^{\circ} \mathrm{C}$ in a shaking incubator $(250 \mathrm{rpm})$. Aliquots $\left(1.0 \mathrm{ml}\right.$ at an $\mathrm{OD}_{600}$ of 1.5) were then used to inoculate $(100 \mathrm{ml})$ the various media employed during this study. Following inoculation, the model strain was incubated at $37{ }^{\circ} \mathrm{C}$ in the various media until an $\mathrm{OD}_{600}$ of 0.6 was attained, followed by addition of IPTG to a final concentration of $75 \mu \mathrm{M}$ in order to induce expression of the recombinant protein. Expression was allowed to proceed for $6 \mathrm{~h}$ at $25^{\circ} \mathrm{C}$. Samples were then taken and stored $\left(-80^{\circ} \mathrm{C}\right)$ until used for biomass determination (section "Total phosphorus (TP) analysis") and determination of recombinant protein production levels and functionality (section "Biomass analysis").

\section{Media composition and P minimization}

The compositions of (LB) broth, terrific broth (TB) and minimal media 9 supplemented with yeast extract (M9/YE) are presented in Table 1 (Sambrook and Russell 2001).

Phosphorus minimization studies were undertaken by reducing the amount of exogenous $\mathrm{P}$ salts $\left(\mathrm{KH}_{2} \mathrm{PO}_{4}\right.$, $\mathrm{K}_{2} \mathrm{HPO}_{4}$ and $\mathrm{NaH}_{2} \mathrm{PO}_{4} \cdot 7 \mathrm{H}_{2} \mathrm{O}$ ) added to $\mathrm{TB}$ and $\mathrm{M} 9 / \mathrm{YE}$ media by $0,50,70,90$ and $100 \%$. In addition, $100 \%$ P-reduced TB and M9/YE supplemented with bis-tris propane buffer, final concentration $50 \mathrm{mM}$, were generated and tested.

Table 1 Compositions of the media employed during this study

\begin{tabular}{lllc}
\hline Component $\left(\mathrm{g} \mathrm{l}^{-1}\right)$ & \multicolumn{3}{l}{ Medium } \\
\cline { 2 - 4 } & LB & TB & M9/YE \\
\hline Tryptone & 10.00 & 12.00 & - \\
Yeast extract & 5.00 & 24.00 & 2.00 \\
$\mathrm{NaCl}$ & 10.00 & - & 0.50 \\
Glycerol & - & $4 \%(\mathrm{v} / \mathrm{v})$ & - \\
Glucose & - & - & 4.00 \\
$\mathrm{KH}_{2} \mathrm{PO}_{4}$ & - & 2.31 & 3.00 \\
$\mathrm{~K}_{2} \mathrm{HPO}_{4}$ & - & 12.54 & - \\
$\mathrm{Na}_{2} \mathrm{HPO}_{4} \cdot 7 \mathrm{H}_{2} \mathrm{O}$ & - & - & 12.80 \\
$\mathrm{NH}_{4} \mathrm{Cl}$ & - & - & 1.00 \\
$\mathrm{MgSO}_{4}$ & - & - & 0.20 \\
$\mathrm{CaCl}_{2}$ & - & - & 0.01 \\
\hline
\end{tabular}


Total phosphorus (TP) analysis

The TP of all fermentation media was determined by 4,500-P analysis as described in standard methods for the examination of water and wastewater (APHA 1995).

Biomass analysis

Post-fermentation microbial dry cell weight (DCW) values were determined via an adapted method described by Suárez et al. (1998). Culture samples $(25 \mathrm{ml})$ were transferred into pre-dried and pre-weight sterile tubes which were subsequently centrifuged $\left(7,500 \mathrm{rpm}, 4{ }^{\circ} \mathrm{C}, 25 \mathrm{~min}\right)$. The resulting cell pellets were washed with $10 \mathrm{ml}$ sterile water and again centrifuged $\left(7,500 \mathrm{rpm}, 4{ }^{\circ} \mathrm{C}, 15 \mathrm{~min}\right)$. The pellets were then oven-dried $\left(100{ }^{\circ} \mathrm{C}, 24 \mathrm{~h}\right)$, cooled to room temperature and the $\mathrm{DCW}$ ( $\mathrm{g} \mathrm{l}^{-1}$ media) determined using a four space Pioneer balance (Ohaus, Switzerland).

Protein quantification and analysis of functionality

\section{$\beta$-Galactosidase quantification}

The concentration of recombinant protein produced in E. coli MC1061 was determined via SDS-PAGE analysis coupled to densitometric scanning according to Crespo et al. (2008) with some modifications. Cell pellets were resuspended in $500 \mathrm{mM} \mathrm{NaCl}, 10 \mathrm{mM} \mathrm{Na}_{2} \mathrm{HPO}_{4}, 2.7 \mathrm{mM}$ $\mathrm{KCl}, 1.8 \mathrm{mM} \mathrm{KH}_{2} \mathrm{PO}_{4}, \mathrm{pH} 7.0,10 \mathrm{mM} \mathrm{MgCl}{ }_{2}, 10 \mathrm{mM} \beta$ mercaptoethanol and $20 \mathrm{mg} \mathrm{l}^{-1}$ soybean trypsin inhibitor to a cell concentration of $20 \mathrm{mg}(\mathrm{DCW}) \mathrm{ml}^{-1}$. The cell suspensions were sonicated (30 s bursts for $20 \mathrm{~min}$ with intermittent cooling) and subsequently centrifuged $\left(10,000 \mathrm{rpm}, 4{ }^{\circ} \mathrm{C}, 10 \mathrm{~min}\right)$. The soluble fractions (supernatant), non-soluble fractions (pellet) and total protein fractions (solution prior to centrifugation) were run on $7 \%$ SDS-PAGE gels (Sambrook and Russell 2001). This was followed by staining of the protein bands with EZBlue according to the product specification with the addition of a fixing step for 15 min using $10 \%$ (v/v) acetic acid and $50 \%(\mathrm{v} / \mathrm{v})$ methanol. Densitometric analysis was undertaken using a UVP biospectrum 410 imaging system and the Vision Works software (Ultra-Violet Ltd., Cambridge). A standard curve of commercial $\beta$-galactosidase concentration $\left(0-200 \mu \mathrm{g} \mathrm{ml}^{-1}\right)$ versus density of the protein bands was generated for quantification.

\section{Enzyme assay}

$\beta$-Galactosidase activity was assayed according to the method of Steers et al. (1971), with some modifications. Ortho-nitrophenyl- $\beta$-D-galactopyranoside (ONPG) substrate was dissolved to a final concentration of $5 \mathrm{mM}$ in
$100 \mathrm{mM}$ sodium phosphate, $10 \mathrm{mM} \mathrm{MgCl}_{2}$ and $20 \mathrm{mg} \mathrm{l}^{-1}$ soybean trypsin inhibitor $\mathrm{pH}$ 6.5. The assay mixture contained $0.4 \mathrm{ml}$ ONPG and $0.1 \mathrm{ml}$ of enzyme suitably diluted in the same buffer. The reaction was allowed to proceed for $15 \mathrm{~min}$ at $50{ }^{\circ} \mathrm{C}$ and was stopped by the addition of $0.5 \mathrm{ml}$ of $1.0 \mathrm{M}$ sodium carbonate, followed by determination of absorbance at $420 \mathrm{~nm}$. One unit of $\beta$-galactosidase activity was defined as the amount of enzyme capable of releasing $1 \mu \mathrm{mol}$ of ONP $\mathrm{min}^{-1}$ under the defined assay conditions.

Kinetic data were obtained by assaying the soluble crude extract of the model strain expressed in the various media. Determination of the kinetic constants was achieved by monitoring the rate of ONPG hydrolysis over time at substrate concentrations ranging from 0.1 to $2.0 \mathrm{mM}$. Lineweaver-Burk plots and initial velocity against substrate concentration plots were constructed allowing determination of the kinetic parameters.

Statistical analysis

Data are reported as mean \pm standard deviation (SD). The generated data were evaluated using one-way analysis of variance (ANOVA). The analysis was performed using the statistical software package MINITAB Statistical software, Release 15 for Windows, and the level of significance was set at $p<0.05$.

\section{Results and discussion}

\section{Generation of the model strain}

$\beta$-Galactosidase was selected as the model recombinant protein as its molecular biology and biochemistry have been very extensively studied (Juers et al. 2000; Matthews 2005; Fowler and Zabin 1977; Jacobson et al. 1994; Nichols et al. 2007). Moreover, the $E$. coli-derived $\beta$-galactosidase used is a complex protein, its functionally active form being a tetramer with overall molecular weight of $465 \mathrm{kDa}$ (Juers et al. 2000). The enzyme also finds industrial application in the production of galacto-oligosaccharides and is used as a digestive supplement for the alleviation of lactose intolerance (O'Connell and Walsh 2007).

The model strain (E. coli MC1061) was chosen as it is devoid of a $\beta$-galactosidase gene, rendering straightforward the development of an engineered (recombinant) strain capable of producing this enzyme via the introduction of a $\beta$-galactosidase coding sequence derived from the $\beta$ galactosidase-positive E. coli strain W3110.

Amplification of the predicted 3,093-bp DNA fragment housing the $\beta$-galactosidase gene from E. coli W3110 genomic DNA was successfully achieved via PCR 

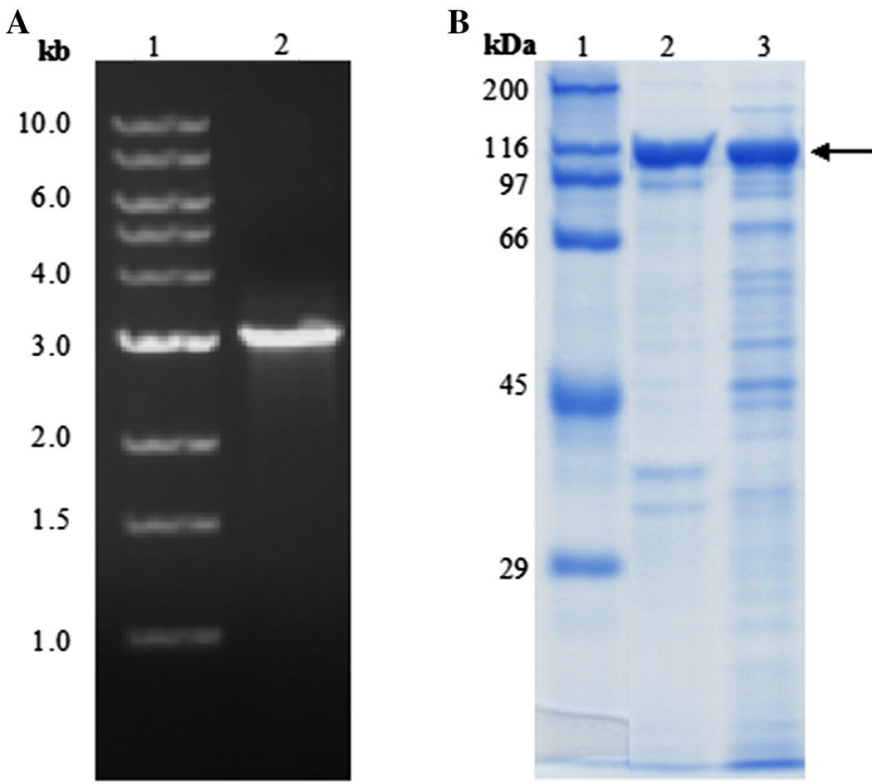

Fig. 1 Key electrophoretic analyses undertaken during the generation of the model strain. a Electrophoretic analysis of PCR amplification at optimized conditions for lac $\mathrm{Z}$ gene from purified gDNA; Lane 1 1-kb DNA ladder (Biolabs), Lane 2 PCR product. b SDS-PAGE analysis of model strain fractions after expression of recombinant protein at $25^{\circ} \mathrm{C}$ for $6 \mathrm{~h}$; Lane 1 Molecular mass marker, Lane 2 non-soluble fraction of model strain, Lane 3 soluble fraction of model strain. c Western blot stained for presence of $\mathrm{His}_{6}$-tag; Lane 1

(Fig. 1a), with successful subsequent protein expression being achieved (Fig. 1b-d). Expression studies in standard LB media were used to maximize soluble $\beta$-galactosidase while also minimizing non-soluble recombinant protein inclusion bodies. The optimal conditions were determined to be an expression temperature of $25^{\circ} \mathrm{C}$ and an IPTG concentration of $75 \mu \mathrm{M}$. Fig. $1 \mathrm{~b}$ illustrates that at these conditions nearly equal amounts of soluble and non-soluble protein were produced. High-level expression of recombinant protein in E. coli often leads to accumulation of varying proportions of the recombinant product as insoluble form, due to overwhelming of the endogenous protein folding machinery (Wilkinson and Harrison 1991). The band of the over-expressed protein shows the anticipated molecular weight (116 kDa) of the $\beta$-galactosidase monomer (Fig. 1b). Western blot analysis (Fig. 1c) confirmed the presence of the poly-histidine tag at the expressed protein, and activity gels (Fig. 1d) illustrate the recombinant protein is functional (i.e., catalytically active). SDSPAGE and Western blot analysis (Fig. 1b, c) showed another $90 \mathrm{kDa}$ band which may be attributed to partially degraded product variant commonly observed in preparations of both native and recombinant $\beta$-galactosidases (Kosinski and Bailey 1991). The native activity gel (Fig. 1d) also indicated the presence of higher-order
C

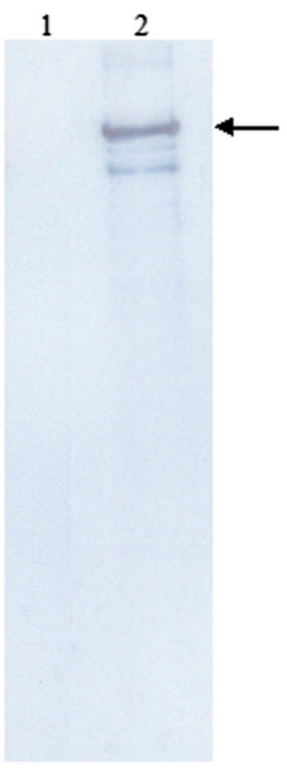

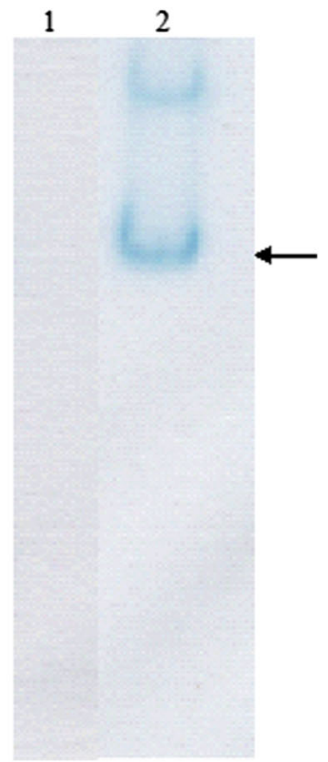

negative control - crude extract from E. coli MC1061 with pProExHTb (no insert), Lane 2 crude extract from E. coli MC1061 carrying pProEx-HTb_lacZ-HT. d Electrophoretic analysis of native gels stained for activity using x-gal; Lane 1 negative control-crude extract from E. coli MC1061 pProEx-HTb; Lane 2 crude extract from E. coli MC1061 pProEx-HTb_lacZ-HT. Arrow points to the expressed recombinant protein

oligomeric forms of $\beta$-galactosidase which are commonly observed during recombinant expression of this enzyme (Juers et al. 2000).

\section{Media analysis}

TB was selected as a representative complex media as it appears to be the more commonly employed media for the production of recombinant proteins in E. coli at laboratory scale (Sambrook and Russell 2001; Atlas 2004; Aristidou et al. 1999). Similar media with complex carbon and nitrogen sources are commonly employed to support high productivity in industrial-scale fermentation systems (Miller and Churchill 1986). M9 or variations thereof (often containing YE in order to improve biomass yield), on the other hand, is one of the most frequently used chemically defined media for E. coli fermentation (Sambrook and Russell 2001). It was also included in this study, as the use of more defined, as opposed to complex media is likely to be a trend evident in the manufacture of recombinant therapeutic proteins. The use of chemically defined media often results in more consistent titers; it allows easier process control and monitoring and simplifies downstream processing. The absence of animal-derived raw materials makes these media the safer manufacturing 
Table 2 Contribution of individual media components to the total phosphorus content of $\mathrm{TB}$ and M9/YE media (mean \pm standard deviation, $n=4$ )

\begin{tabular}{lll}
\hline Media component & TP conc. $\left(\mathrm{g} \mathrm{l}^{-1}\right)$ & $\begin{array}{l}\text { TP total conc. } \\
\text { of media }\left(\mathrm{g} \mathrm{l}^{-1}\right)\end{array}$ \\
\hline TB & & \\
$\quad$ Tryptone & $0.07 \pm 0.003$ & $2.76 \pm 0.138$ \\
Yeast extract & $0.26 \pm 0.012$ & \\
$\mathrm{KH}_{2} \mathrm{PO}_{4}$ & $0.50 \pm 0.051$ & \\
$\mathrm{~K}_{2} \mathrm{HPO}_{4}$ & $1.92 \pm 0.048$ & \\
$\mathrm{M} 9 / \mathrm{YE}$ & \\
$\mathrm{Yeast} \mathrm{extract}$ & $0.03 \pm 0.003$ & $1.77 \pm 0.114$ \\
$\mathrm{KH}_{2} \mathrm{PO}_{4}$ & $0.58 \pm 0.080$ & \\
$\mathrm{Na}_{2} \mathrm{HPO}_{4} \cdot 7 \mathrm{H}_{2} \mathrm{O}$ & $1.15 \pm 0.048$ & \\
\hline
\end{tabular}

option and reduces extensive testing of raw materials (Zhang and Greasham 1999; Tripathi et al. 2009).

Direct TP analysis (section "Cell growth, recovery, and lysis") of the individual components of TB and M9/YE (made up as individual solutions to their final equivalent concentration in finished media) predictably identified the exogenous phosphate salts $\left(\mathrm{KH}_{2} \mathrm{PO}_{4}, \mathrm{~K}_{2} \mathrm{HPO}_{4}\right.$ and $\mathrm{Na}_{2} \mathrm{HPO}_{4}$ ) as the major contributor of the overall media $\mathrm{P}$ content (Table 2). The additional complex ingredients (YE or tryptone) also contributed relatively minor amounts of the TP.

For the $\mathrm{P}$ minimization study, only the amount of chemically defined exogenous $\mathrm{P}\left(\mathrm{KH}_{2} \mathrm{PO}_{4}, \mathrm{~K}_{2} \mathrm{HPO}_{4}\right.$ and $\mathrm{Na}_{2} \mathrm{HPO}_{4} \cdot 7 \mathrm{H}_{2} \mathrm{O}$ ) added to the TB and M9/YE media was reduced as any reduction in tryptone, and YE would also reduce the concentration of all the other nutrients therein essential for $E$. coli growth. The exogenous $\mathrm{P}$ was reduced by $50,70,90$ and $100 \%$ in both types of media, resulting in TP concentrations of 1.47, 1.12, 0.53 and $0.39 \mathrm{~g}^{-1}$ for $\mathrm{TB}$ and $0.93,0.52,0.21$ and $0.02 \mathrm{~g}^{-1}$ for M9/YE.

\section{Effect of P minimization on biomass}

Table 3 presents the findings of stepwise $\mathrm{P}$ reduction upon cellular growth. The results indicate that a reduction in $\mathrm{P}$ salts added to TB or to M9/YE of up to $70 \%$ does not impact upon biomass yield achieved, with no statistically significant difference in the mean DCW values of 0,50 and $70 \%$ P-reduced media in either case.

Decreasing the $\mathrm{P}$ salts further did lead to a fall in mean DCW obtained. The reduction recorded in the case of TB was moderate, as the mean $\mathrm{g}(\mathrm{DCW}) \mathrm{l}^{-1}$ values for $100 \%$ P-reduced TB declined by $<15 \%$ compared to unaltered media.

The effect of $\mathrm{P}$ reduction by more than $70 \%$ on the semi-defined M9/YE media was more pronounced and led to significant decrease in cellular mass. The DCW of the $90 \%$ P-reduced semi-defined media resulted in a drop of biomass by 35 and $100 \%$ P reduced only gave about $30 \%$ of the overall cell yield.

The decrease in overall biomass yields upon reduction of $\mathrm{P}$ in semi-defined media is most likely due to a drop in $\mathrm{pH}$ during growth of the cells and expression of the recombinant protein. The $\mathrm{pH}$ of the $\mathrm{TB}$ media pre- and post-fermentation at all $\mathrm{P}$ concentrations remained relatively constant $(\mathrm{pH}$ 6.8-7.3). In the case of the M9/YE media, at $\mathrm{P}$ levels of $90 \%$ and below, the post-fermentation media $\mathrm{pH}$ had dropped from 7.3 to $\mathrm{pH} \leq 5$.

Escherichia coli produces acetic acid during aerobic fermentation and without the $\mathrm{P}$ salts as a buffering component the $\mathrm{pH}$ in the media drops (Cappucino and Sherman 2005). Ammonia-containing chemicals such as ammonium chloride and ammonium sulfate also act as buffering compounds in media, and their consumption during growth slowly deceases the buffering capacity of the media, thereby resulting in a further $\mathrm{pH}$ drop (Krause et al. 2010). At the point of inoculation, the $\mathrm{pH}$ of the media was within the optimum $\mathrm{pH}$ range for $E$. coli, but during the growth

Table 3 Reduction in phosphorus and its effects on mean dry cell weight values obtained for TB and M9/YE media $0 \% \mathrm{P}$ reduced $=$ control (complete) media, as per Table 1 (mean \pm standard deviation, $n=12$ )

\begin{tabular}{llllll}
\hline \% P reduction & $\mathrm{TB}$ & & \multicolumn{2}{l}{ M9/YE } \\
\cline { 2 - 3 } \cline { 5 - 6 } \cline { 5 - 6 } & Mean $\mathrm{g}(\mathrm{DCW}) 1^{-1}$ & \% Mean in comparison with control & & Mean $\mathrm{g}(\mathrm{DCW}) 1^{-1}$ & \% Mean in comparison with control \\
\hline 0 & $1.00 \pm 0.09$ & 100 & 99.9 & $0.87 \pm 0.14$ & 100 \\
50 & $1.00 \pm 0.06$ & 97.4 & $0.83 \pm 0.06$ & 94.9 \\
70 & $0.98 \pm 0.09$ & 90.7 & $0.83 \pm 0.07$ & 95.7 \\
90 & $0.91 \pm 0.09^{\mathrm{a}}$ & 85.9 & $0.57 \pm 0.09^{\mathrm{c}}$ & 65.6 \\
100 & $0.86 \pm 0.10^{\mathrm{b}}$ & 97.7 & $0.27 \pm 0.09^{\mathrm{d}}$ & 30.7 \\
Bis-tris propane* & $0.98 \pm 0.07$ & $0.64 \pm 0.03$ & 73.6 \\
\hline
\end{tabular}

* Phosphate salts replaced by $50 \mathrm{mM}$ bis-tris propane buffer

${ }^{\mathrm{a}} p=0.005,{ }^{\mathrm{b}} p<0.001$

${ }^{\mathrm{c}} p<0.001,{ }^{\mathrm{d}} p<0.001$ 
and expression of recombinant protein, the $\mathrm{pH}$ dropped to a level at which the bacteria are no longer viable.

The complex ingredients in TB contain amino acids, peptones and proteins, which are amphoteric compounds and thereby act as natural buffers (Cappucino and Sherman 2005 ) preventing a considerable change in $\mathrm{pH}$. The drop in $\mathrm{pH}$ associated with the semi-defined media could likely be counteracted at industrial level by continuous, automated $\mathrm{pH}$ adjustment during fermentation, a facility associated with industrial-scale fermentation systems.

Support for this hypothesis is provided by a supplementary study in which the $100 \%$ phosphorous-reduced M9/YE media was supplemented with $50 \mathrm{mM}$ bis-tris propane buffer, $\mathrm{pH}$ 7.4. Inclusion of this buffer resulted in a mean postfermentation $\mathrm{pH}$ witnessed of 5.6, as supposed to $4.7(n=3)$ and decreased the mean drop in biomass observed (relative to the $0 \%$ P-reduced media) from 69.3 to $26.4 \%$ (Table 3 ).

\section{Expression levels achieved}

The model strain expressed the recombinant $\beta$-galactosidase in two fractions, as soluble functional protein (soluble fraction) and as non-soluble misfolded inclusion bodies (insoluble fraction). This is a common characteristic of recombinant protein expression in E. coli (Sambrook and Russell 2001). Electrophoretic analysis of the negative control (E. coli MC1061 pProEx-HTb no insert) showed that there were no visible bands with molecular masses of approximately $116 \mathrm{kDa}$ (Fig. 2a). Therefore, the concentrations $\left(\mathrm{mg} \mathrm{g}(\mathrm{DCW})^{-1}\right.$ ) of recombinant protein present in both soluble and non-soluble fractions as well as the total $\beta$ galactosidase concentration of the combined fractions were determined as outlined (section "Protein quantification and analysis of functionality"). (Fig. 2b, c and Table 4).

There is no statistically significant difference between the mean concentrations of total $\beta$-galactosidase $(p>0.05)$ produced when using TB at any $\mathrm{P}$ concentration although a moderate fall in total recombinant protein $(13.3 \%)$ is recorded $\left(18.2 \mathrm{v} 15.8 \mathrm{mg} \mathrm{g}(\mathrm{DCW})^{-1}\right.$; control v $100 \% \mathrm{P}$ reduced, respectively), caused by the reduced amount of non-soluble recombinant protein produced only. The recombinant protein production conditions used during this study achieve high levels of $\beta$-galactosidase expression. It is likely that the high local concentrations of the product with insufficient amount of folding-promoting proteins lead to the formation of inclusion bodies (Krause et al. 2010). The reduction of $\mathrm{P}$ in the media may result in a marginally reduced overall protein synthesis rate which slightly decreases the overall protein concentration but allows the same amount of soluble protein to be formed.

A reduction of up to $70 \% \mathrm{P}$ in the $\mathrm{M} 9 / \mathrm{YE}$ media was possible without causing a statistically significant difference in the concentration of recombinant protein produced. Any further $\mathrm{P}$ minimization lead to a notable decline of both soluble and non-soluble $\beta$-galactosidase fractions and therefore total protein concentration as seen in Table 4.

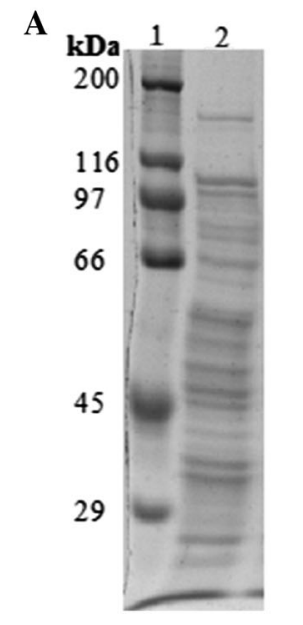

Fig. 2 SDS-PAGE analysis of total protein fractions of model strain during phosphorus minimization study. Amount of biomass loaded for each sample normalized $\left(20 \mathrm{mg}(\mathrm{DCW}) \mathrm{ml}^{-1}\right.$ ). Recombinant protein is highlighted. a Negative control. Lane 1 Molecular mass marker; Lane 2 total protein fraction of E. coli MC1061 pProEx-HTb (no insert). b P-minimization study in TB media. Lane 1 Molecular mass marker; Lane 2 total protein fraction of model strain expressed in TB; Lane 3 total protein fraction of model strain expressed in TB $50 \% \mathrm{P}$ reduced; Lane 4 total protein fraction of model strain expressed in TB $70 \% \mathrm{P}$ reduced; Lane 5 total protein fraction of model strain expressed in TB $90 \%$ P reduced; Lane 6 total protein fraction of model strain expressed in TB $100 \% \mathrm{P}$ reduced; Lane $70.75 \mu \mathrm{g} \beta$ galactosidase standard; Lane $81.5 \mu \mathrm{g} \beta$-galactosidase standard. c P minimization study in M9/YE media. Lane 1 Molecular mass marker; Lane 2 total protein fraction of model strain expressed in M9/YE; Lane 3 total protein fraction of model strain expressed in M9/YE $50 \% \mathrm{P}$ reduced; Lane 4 total protein fraction of model strain expressed in M9/YE $70 \% \mathrm{P}$ reduced; Lane 5 total protein fraction of model strain expressed in M9/YE $90 \% \mathrm{P}$ reduced; Lane 6 total protein fraction of model strain expressed in M9/YE $100 \% \mathrm{P}$ reduced; Lane $70.75 \mu \mathrm{g} /$ per lane $\beta$-galactosidase standard; Lane 8 $1.5 \mu \mathrm{g} / \mathrm{per}$ lane $\beta$-galactosidase standard 
Table 4 Percent phosphorus reduction and its effects on recombinant protein expression in TB and M9/YE media $0 \% \mathrm{P}$ reduced $=$ control (complete) media, as per table 1 (mean \pm standard deviation, $n=6$ )

\begin{tabular}{|c|c|c|c|c|}
\hline \multirow{2}{*}{$\begin{array}{l}\% \mathrm{P} \\
\text { reduction }\end{array}$} & \multicolumn{2}{|l|}{ TB } & \multicolumn{2}{|l|}{ M9/YE } \\
\hline & $\begin{array}{l}\text { Concentration of total } \beta \text {-galactosidase } \\
{[\mathrm{mg} \beta \text {-gal } / \mathrm{g}(\mathrm{DCW})]}\end{array}$ & $\begin{array}{l}\% \text { Mean in comparison } \\
\text { with control }\end{array}$ & $\begin{array}{l}\text { Concentration of total } \beta \text {-galactosidase } \\
{[\mathrm{mg} \beta \text {-gal } / \mathrm{g}(\mathrm{DCW})]}\end{array}$ & $\begin{array}{l}\% \text { Mean in comparison } \\
\text { with control }\end{array}$ \\
\hline 0 & $18.2 \pm 2.4$ & 100 & $13.2 \pm 0.5$ & 100 \\
\hline 50 & $17.5 \pm 2.1$ & 96.5 & $13.4 \pm 0.7$ & 101.7 \\
\hline 70 & $17.5 \pm 2.8$ & 96.1 & $12.8 \pm 1.2$ & 97.4 \\
\hline 90 & $15.9 \pm 2.8$ & 87.6 & $8.5 \pm 1.5^{\mathrm{a}}$ & 64.3 \\
\hline 100 & $15.8 \pm 2.2$ & 86.7 & $5.5 \pm 0.6^{\mathrm{b}}$ & 41.6 \\
\hline
\end{tabular}

${ }^{\mathrm{a}} p<0.001,{ }^{\mathrm{b}} p<0.001$

This may also be due to the decrease in $\mathrm{pH}$ observed during fermentation. The drop in $\mathrm{pH}$ due to accumulation of acetate not only impairs cell growth but can negatively affect the rate of recombinant protein synthesis (Krause et al. 2010).

\section{Quality of recombinant protein}

It was established from the DCW determination, and the recombinant protein quantification that a reduction of $\mathrm{P}$ salts up to $70 \%$ in both $\mathrm{TB}$ and M9/YE was possible without adversely affecting biomass or protein yields. The routine industrial use of such P-reduced media would only be applied in practice if the decrease in TP did not negatively affect the recombinant protein's functional quality. Comparative kinetic analysis was therefore used to assess the functionality of the recombinant $\beta$-galactosidase expressed. The kinetic parameters $\left(k_{\mathrm{m}}\right.$ and $\left.V_{\max }\right)$ were determined from the soluble crude extract of the model strain expressed in unaltered media and media with $70 \% \mathrm{P}$ reduced. The results (Table 5) indicate that the $k_{\mathrm{m}}$ and $V_{\max }$ values recorded are not influenced by type of media or the amount of $\mathrm{P}$ salts present in it. Therefore, expression of $\beta$ galactosidase in P-reduced media did not negatively impact on the quality of the recombinant protein.

Potential savings of $\mathrm{P}$ during large-scale manufacturing

The study provides laboratory-scale proof of principle that a reduction in added $\mathrm{P}$ of up to $70 \%$ bears no negative effect upon production levels or functionality of a model recombinant protein. Phosphorous is not a component of the amino acids from which proteins are synthesized nor is it subsequently incorporated as a post-translational modification into any commercial protein produced in E. coli. Hence, it is very likely that the results presented would be broadly applicable to the production of most if not all recombinant proteins in E. coli. Phosphorous is a core cell nutrient, which therefore will almost certainly primarily effect cell biomass
Table 5 Effect of phosphorus reduction in recombinant protein functional quality as assessed by determining selected kinetic values (mean values \pm standard deviation; $n=4$ )

\begin{tabular}{llllll}
\hline $\begin{array}{l}\% \mathrm{P} \\
\text { reduced }\end{array}$ & $\mathrm{TB}$ & & $\mathrm{M} 9 / \mathrm{YE}$ & \\
\cline { 2 - 3 } \cline { 5 - 6 } & $k_{\mathrm{m}}(\mu \mathrm{M})$ & $\begin{array}{l}V_{\max } \\
\left(\mu \mathrm{M} \min ^{-1}\right)\end{array}$ & & $k_{\mathrm{m}}(\mu \mathrm{M})$ & $\begin{array}{l}V_{\max } \\
\left(\mu \mathrm{M} \min ^{-1}\right)\end{array}$ \\
\hline 0 & $0.76 \pm 0.11$ & $28.21 \pm 3.07$ & $0.84 \pm 0.05$ & $27.66 \pm 1.67$ \\
70 & $0.66 \pm 0.14$ & $24.77 \pm 2.72$ & $0.68 \pm 0.01$ & $26.35 \pm 2.84$ \\
\hline
\end{tabular}

production as opposed to, e.g., protein production independently of cell biomass production. Previous studies have shown that, for $E$. coli, the generalized relationship between growth rate and nutrient consumption is similar between shake flask experiments and batch fermentation (Luli and Strohl 1990; Li et al. 1990; Aristidou et al. 1999). Variations of process parameters such as variations in growth conditions (e.g., exact nutrient composition, $\mathrm{pH}$, temperature, dissolved oxygen concentration) or fermentation format/scale, when undertaken in a $70 \%$ reduced P-containing media, while almost certainly affecting the biomass yield attained, would therefore likely have little effect upon the ratio of protein to biomass produced.

Quantitative data concerning total annual global E. colibased fermentation capacity are not available. However, a significant proportion (likely the majority) of E. coli-based fermentation is used to produce recombinant therapeutic proteins. The total quantity of finished (purified final product) microbial-derived biopharmaceuticals produced in 2010 was estimated at $17,880 \mathrm{~kg}$ (Ransohoff 2011). Assuming a maximum downstream processing yield of $30 \%$ and an expression level of $5 \mathrm{~g}$ recombinant protein per liter media (Ho 2010), this quantity of finished product equates to some $11.92 \times 10^{6} 1$ of fermentation media used. A reduction of $70 \%$ of exogenous $\mathrm{P}$ levels in this quantity of TB media would equate to a saving of $20,192 \mathrm{~kg}$, while a $70 \%$ reduction in the exogenous $\mathrm{P}$ levels of M9/YE media would equate to a $14,435-\mathrm{kg}$ savings in total $\mathrm{P}$, respectively. 


\section{Conclusion}

It has been shown that the $\mathrm{P}$ concentration in two commonly used $E$. coli fermentation media can be reduced very significantly before a negative impact on biomass yield and recombinant protein production is observed. If translated to industrial scale, a $70 \%$ reduction in exogenous $\mathrm{P}$ added to such media would result in the saving of $14,000-20,000 \mathrm{~kg}$ $\mathrm{P}$ on an annual basis in the biopharmaceutical sector alone. Such reductions would result in a much cleaner manufacturing process, placing significantly less pressure on waste stream treatment facilitates and reduce the risk of eutrophication if accidental waste stream discharge was to occur. It would also result in manufacturing cost savings and assist in slowing the rate of depletion of natural $\mathrm{P}$ resources.

Acknowledgments This project is funded as part of the Science, Technology, Research and Innovation for the Environment (STRIVE) Programme 2007-2013. The programme is financed by the Irish Government under the National Development Plan 2007-2013 (Grant number 2008-S-ET-1), and it is administered on behalf of the DEHLG by the Environmental Protection Agency (EPA) which has the statutory function of coordinating and promoting environmental research.

\section{References}

APHA (1995) Standard Methods for the examination of water and wastewater, 19th edn. American Health Association, Washington

Aristidou AA, San K-Y, Bennett GN (1999) Improvement of biomass yield and recombinant gene expression in Escherichia coli by using fructose as the primary carbon source. Biotechnol Prog 15(1):140-145

Atlas RM (2004) Handbook of microbiological media, 3rd edn. CRC Press, Boca Raton

Behme S (2009) Manufacturing of pharmaceutical protein: from technology to economy. Wiley, Weinheim

Cappucino JG, Sherman N (2005) Microbiology: a laboratory manual, 7th edn. Benjamin Cummings, San Franscisco

Choi JH, Keum KC, Lee SY (2006) Production of recombinant proteins by high cell density culture of Escherichia coli. Chem Eng Sci 61(3):876-885

Cliffe FE, Walsh G, O'Dwyer TF (2010) Utilisation of phosphorus nutrient content in industrial scale plasmid DNA production: a waste minimisation study. J Clean Prod 18(10-11):1066-1072. doi:10.1016/j.jclepro.2010.02.013

Crespo AL, Spencer TA, Nekl E, Pusztai-Carey M, Moar WJ, Sigfried BD (2008) Comparison and Validation of methods to quantify Cry1 Ab toxin from Bacillus thuringiensis for standardization of insect bioassays. Appl Environ Microbiol 74(1):130-135

Demain AL, Vaishnav P (2009) Production of recombinant proteins by microbes and higher organisms. Biotechnol Adv 27(3):297-306

Eiteman MA, Altman E (2006) Overcoming acetate in Escherichia coli recombinant protein fermentations. Trends Biotechnol 24(11):530-536

Fowler AV, Zabin I (1977) The amino acid sequence of $\beta$ galactosidase of Escherichia coli. Proc Natl Acad Sci USA 74(4):1507-1510
Ho SV (2010) Environmental considerations in biologics manufacturing. In: Dunn PJ, Wells AS, Williams MT (eds) Green chemistry in the pharmaceutical industry. Wiley, Weinhaim, pp 311-331

Jacobson RH, Zhang XJ, DuBose RF, Matthews BW (1994) Threedimensional structure of $\beta$-galactosidase from $E$. coli. Nature 369(6483):761-766

Juers DH, Jacobson RH, Wigley D, Zhang XJ, Huber RE, Tronrud DE, Matthews BW (2000) High resolution refinement of $\beta$ galactosidase in a new crystal form reveals multiple metalbinding sites and provides a structural basis for alpha-complementation. Prot Sci 9(9):1685-1699

Khan FA, Ansari AA (2005) Eutrophication: an ecological vision. Bot Rev 71(4):449-482

Kosinski MJ, Bailey JE (1991) Temperature and induction effects on the degradation rate of an abnormal $\beta$-galactosidase in Escherichia coli. J Biotechnol 18(1-2):55-68

Krause M, Ukkonen K, Haataja T, Ruottinen M, Glumoff T, Neubauer A, Neubauer P, Vasala A (2010) A novel fed-batch based cultivation method provides high cell-density and improves yield of soluble recombinant proteins in shaken cultures. Microb Cell Fact 9(1):11-22

Li X, Robbins JW Jr, Taylor KB (1990) The production of recombinant beta-galactosidase in Escherichia coli in yeast extract enriched medium. J Ind Microbiol 5(2-3):85-93. doi:10. 1007/bf01573857

Luli GW, Strohl WR (1990) Comparison of growth, acetate production, and acetate inhibition of Escherichia coli strains in batch and fed-batch fermentations. Appl Environ Microbiol 56(4):1004-1011

Matthews BW (2005) The structure of E. coli $\beta$-galactosidase. CR Biol 328(6):549-556

Miller T, Churchill BW (1986) Substrates for large-scale fermentations. In: Demain AL, Solomon NA (eds) Manual of industrial microbiology and biotechnology. ASM Press, Washington, pp 122-136

Nichols E, Gavina J, McLeod R, Craig D (2007) Single molecule assays of $\beta$-galactosidase from two wild-type strains of $E$. coli: effects of protease inhibitors on microheterogeneity and different relative activities with differing substrates. Protein J 26(2):95-105. doi:10.1007/s10930-006-9050-3

O'Connell S, Walsh G (2007) Purification and properties of a $\beta$ galactosidase with potential application as a digestive supplement. Appl Biochem Biotechnol 141(1):1-13

Ransohoff TC (2011) Global trends in mammalian cell culture capacity and biomanufacturing. In: Paper presented at the Swiss Biotech Program at BioPharm America 2011 Boston, MA, Sept 2011

Sambrook J, Russell DW (2001) Molecular cloning: a laboratory manual, 3rd edn. Cold Spring Harbor Laboratory Press, New York

Steers E Jr, Cuatrecasas P, Pollard HB (1971) The purification of $\beta$ galactosidase from Escherichia coli by affinity chromatography. J Biol Chem 246(1):196-200

Suárez DC, Liria CW, Kilikian BV (1998) Effect of yeast extract on Escherichia coli growth and acetic acid production. World J Microbiol Biotechnol 14(3):331-335. doi:10.1023/a: 1008800908696

Tripathi NK, Sathyaseelan K, Jana AM, Rao PVL (2009) High yield production of heterologous proteins with Escherichia coli. Def Sci J 59(2):137-146

Wilkinson DL, Harrison RG (1991) Predicting the solubility of recombinant proteins in Escherichia coli. Nat Biotechnol 9(5):443-448

Zhang J, Greasham R (1999) Chemically defined media for commercial fermentations. Appl Microbiol Biotechnol 51(4):407-421 